\title{
高強度・高流動コンクリートの 地下連続壁への適用に関する研究
}

坂本淳 ${ }^{1} \cdot$ 大友健 $^{2} \cdot$ 新藤竹文 $^{3} \cdot$ 松岡康訓 $^{4}$

\footnotetext{
1 正会員 工修 大成建設株式会社技術研究所（テ245-0051 神奈川県横浜市戸塚区名瀬町 344-1）

2 正会員 工博 大成建設株式会社技術研究所（广245-0051 神奈川県横浜市戸塚区名瀬町 344-1)

3 正会員 工博 大成建設株式会社技術研究所（†245-0051 神奈川県横浜市戸塚区名瀬町 344-1） ${ }^{4}$ フェロー会員 工博 大成建設株式会社技術研究所（テ245-0051 神奈川県横浜市戸塚区名瀬町 344-1）
}

本研究では, 地下連続壁を対象とした配合強度 $80 \mathrm{~N} / \mathrm{mm}^{2}$ 以上の高強度・高流動コンクリートの配合を検討し, 地下 連続壁を模擬した試験体, および実大規模の地下連続壁への打設実験を行った. その結果, 低熱ポルトランドセメント を主体とした結合材とポリカルボン酸系高性能 AE減水剤を使用した配合は硬化時の温度上昇量が小さく, 長期の強度 発現性が良好であること,一般のレディミクストコンクリート工場においても連続的に安定した品質のものが製造可能 であり，通常の連壁コンクリートと同様にトレミーエ法による打込みが可能であることを示した. また, コンクリート のスランプフロー経時変化を調べることは有効な側圧管理手法となること,構造体の強度は打込み時に採取した標準養 生供試体とほほ同等の強度を有したが, その変動釈数はやや増加する傾向がみられることを示した.

Key Words : high strength, self compacting concrete, underground diaphragm wall

1.はじめに

地下連続壁工法は土留め壁等の地下工事に欠かすこ とのできない工法であり, 近年はその大深度化·大型化 に伴い地下連続壁の壁厚が増大し, 配筋が過密になる傾 向にある.

しかし, 地下タンク構造物等コンクリートの圧縮強度 により壁の厚さが支配される構造物においては, 従来よ り使用されてきた設計基準強度 $370 \mathrm{~kg} \mathrm{f} / \mathrm{cm}^{2}\left(3 \mathbb{N} / \mathrm{mm}^{2}\right)$ 程度より高い強度のコンクリートを使用することで, コ ンクリート数量や掘削残土を少なくでき掘削機械の小 型化も図れることから, 省資源化や建設工費の低減が可 能となる.

ただし，一般に高強度コンクリートは粘性が高くなる ため，地下連続壁の施工で通常採られているトレミ一管 を用いた自重充てんによる打込みが難しくなり, 過密配 筋への充てんも困難となる. また, 単位結合材量の増大 に伴い, 硬化時の水和熱が高くなるため, 温度ひび割れ の発生の可能性が高くなる.このような問題に対する材 料およひ配合上での対応策としては, 高性能 $\mathrm{AE}$ 減水剤 の使用による高流動化, 低熱ポルトランドセメント,フ
ライアッシュ等の使用による低発熱化等か棌られてい る(1)-3).

このような高強度・高流動コンクリートの地下連続壁 への適用は近年増しているが4)，その構造体の品質につ いて検証された例は少ない. 本研究は, 高強度・高流動 コンクリートの地下連続壁への適用性を検証すること を目的に行われた，配合選定実験や実規模地下連続壁へ の打設実験等の結果 ${ }^{5)}$ ９）をまとめたものである.

\section{2. 高強度・高流動コンクリートの 配合選定実験}

\section{（1）実験内容}

\section{a)目標性能}

本研究においては，一般的に入手できる材料を使用し， 市中のレディミクストコンクリート工場において製造 が可能であることを前提条件として, コンクリートの目 標性能を設定すると共に，材料選定した。設定した目標 性能を, 表-1に示す.

強度特性としては, 材齢91 日で80 90N/ $\mathrm{mm}^{2}$ の圧縮強 
表-1 コンクリートの目標性能

\begin{tabular}{|c|c|c|}
\hline 評価項目 & 評価指摽 & 目標値 \\
\hline 流動性 & スランプフロー & $68 \pm 5 \mathrm{~cm}$ \\
\hline 分離抵抗性 & $500 \mathrm{~mm}$ フロー到達時間 & $3 \sim 10$ 秒 \\
\hline 充てん性 & 充てん高さ & $\begin{array}{c}30 \mathrm{~cm} \text { 以上 } \\
\text { (障害条件R2) }\end{array}$ \\
\hline 強度特性 & 圧縮強度 & $\begin{array}{c}80 \sim 90 \mathrm{~N} / \mathrm{mm} \\
\text { (材齢91日) }\end{array}$ \\
\hline
\end{tabular}

表-3 試験方法

\begin{tabular}{|c|c|}
\hline 試験項目 & 試験方法 \\
\hline スランプフロー & \multirow{2}{*}{ スランプフロー試験 } \\
\hline $500 \mathrm{~mm}$ フロー到達時間 & \\
\hline 空気量 & 空気量試験 \\
\hline 充てん高さ & $\begin{array}{c}\text { U形充てん装嘈による } \\
\text { 間げき通過性試験注 }\end{array}$ \\
\hline 圧縮強度 & $\begin{array}{c}\text { 圧縮強度試験 } \\
\text { (JIS A 1108に準拠) }\end{array}$ \\
\hline
\end{tabular}

注）参考文献10）に示される土木学会規準(案)に準拠

表-2 配合および使用材料

\begin{tabular}{|c|c|c|c|c|c|c|c|c|c|c|c|c|c|}
\hline \multirow{3}{*}{$\begin{array}{l}\text { 配合 } \\
\text { No. }\end{array}$} & \multirow{3}{*}{$\begin{array}{l}G_{\max } \\
(\mathrm{mm})\end{array}$} & \multirow{3}{*}{$\begin{array}{l}\text { W/B } \\
(\%)\end{array}$} & \multirow{3}{*}{$\begin{array}{l}\text { s/a } \\
(\%)\end{array}$} & \multicolumn{10}{|c|}{ 単位量（kg/m'） } \\
\hline & & & & \multirow{2}{*}{$\begin{array}{l}\text { 水 } \\
W\end{array}$} & \multicolumn{4}{|c|}{ 結合材 B } & \multirow{2}{*}{ S } & \multirow{2}{*}{ G } & \multicolumn{2}{|c|}{ 高性能(AE)減水剂 } & \multirow{2}{*}{ 増粘剤 } \\
\hline & & & & & OBF & OP & LP & $\mathrm{F}$ & & & SP1 & SP2 & \\
\hline $1-1$ & \multirow{4}{*}{20} & \multirow{4}{*}{30} & \multirow{4}{*}{45} & \multirow{4}{*}{165} & \multirow{2}{*}{350} & \multirow{2}{*}{200} & \multirow{2}{*}{-} & \multirow{2}{*}{-} & \multirow{2}{*}{707} & \multirow{2}{*}{908} & 13.8 & - & \multirow{4}{*}{0.5} \\
\hline $1-2$ & & & & & & & & & & & - & 11.0 & \\
\hline $2-1$ & & & & & \multirow{2}{*}{ - } & \multirow{2}{*}{-} & \multirow{2}{*}{500} & \multirow{2}{*}{50} & \multirow{2}{*}{717} & \multirow{2}{*}{921} & 12.1 & - & \\
\hline $2-2$ & & & & & & & & & & & - & 10.5 & \\
\hline
\end{tabular}

\begin{tabular}{|c|c|c|}
\hline 種 類 & 記号 & 品 \\
\hline \multirow{4}{*}{ 結合材 } & OBF & 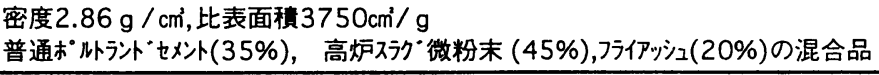 \\
\hline & OP & 普通ポルトランドセメント，密度 $3.16 \mathrm{~g} / \mathrm{cm}^{\prime}$,比表面積 $3270 \mathrm{~cm}^{2} / \mathrm{g}$ \\
\hline & LP & 低熱ポルトランドセメント, 密度 $3.22 \mathrm{~g} / \mathrm{cm}^{\prime}$,比表面積 $3390 \mathrm{~cm}^{2} / \mathrm{g}$ \\
\hline & $\mathrm{F}$ & フライアッシュ, 密度 $2.26 \mathrm{~g} / \mathrm{cm}^{\prime}$, 比表面積 $3020 \mathrm{~cm}^{2} / \mathrm{g}$ \\
\hline 細骨材 & S & 木更津産陸砂, 表乾比重2.58, 粗粒率2.55, 実樌率66.1\% \\
\hline 粗骨材 & G & 八戸産石灰砕石, 表乾比重 2.71 , 粗粒率 6.49 , 実樌率 $65.9 \%$ \\
\hline \multirow{2}{*}{ 高性能(AE)減水剂 } & SP1 & ナフタレン系高性能減水剤 \\
\hline & SP2 & ポリカルボン酸系高性能AE減水剤 \\
\hline 增粘剤 & - & 多糖類ポリマー \\
\hline
\end{tabular}

度を目標とした. また, フレッシュ時の性能は流動性に ついてはスランプフロー, 分離抵抗性については $500 \mathrm{~mm}$ フロー到達時間, および充てん性については充てん高さ により評価することとした. 各々の目標值は表-1に示す とおりである.

\section{b検討配合およひ使用材料}

高強度コンクリートは水結合材比を小さくする必要 があるが,一般的には水結合材比が小さいとコンクリー トの粘性が過大になるため, 高流動コンクリートとして 必要な流動性と分離抵抗性のバランスを保つことが困 難となる.

そこで, 本実験では表-1 に示す目標性能が達成可能な 結合材，および高性能(AE)減水剤の材料選定を行うこと を目的とし,これらの材料の種類を検討要因とした数種
の配合について, フレッシュ時の品質, 強度特性, およ ひ断熱温度上昇量について検討した. 本実験において検 討した配合，および使用材料を表2に示す。

結合材としては, 普通ポルトランドセメント, 高炉ス ラグ微粉末, およびフライアッシュから構成された三成 分系プレミックスセメント (OB F ) と普通ポルトラン ドセメントを組合せたもの，および低熱ポルトランドセ メントとフライアッシュを組合せたものを使用した. ま た, 高性能(AE)减水剤としてナフタレン系, およびポり カルボン酸系のものを使用した. さらに, 全ての配合に おいて多糖類ポリマー系の増粘羭を $0.5 \mathrm{~kg} / \mathrm{m}^{3}$ 使用し, 併用系高流動コンクリートの配合とした，なお，空気量 については 4士1\%とした。

表-2に示すように水結合材比, 細骨材率, 単位水量は 
各配合において同一とし, 所要のスランプフローとなる ように高性能(AE)減水剤の添加量を調整した。

\section{C)試験方法}

本実験で実施した各種試験の試験方法を, 表-3に示す。 フレッシュ時の品質評価試験として, スランプフロー試 験，充てん装置を用いた間げき通過性試験等を実施し， また, 硬化後の強度特性は圧縮強度試験により評価した。 さらに, 硬化時の発熱特性を評価するため, 空気循環式 の試験機を用いて配合 1-2,2-2 について断熱温度上昇試 験を行った.

\section{（2）実験結果}

a)フレッシュコンクリートの性状

フレッシュコンクリートの試験結果を表-4に示す. 高 性能(AE)減水剤の添加量を調整してスランプフローが 各配合においてほほ同等となるようにした結果, $500 \mathrm{~mm}$ フロー到達時間は高性能(AE)减水剤の種類により顕著 に異なる値となった. すなわち, ポリカルボン酸系の高 性能 $\mathrm{AE}$ 減水剂を使用すると, ナフタレン系の高性能減 水剂に比較して $500 \mathrm{~mm}$ フロー到達時間は半分程度に短 くなった.この現象には, セメント等のコンクリート中 の微粉末材への高性能(AE)減水剂の分散作用機構が, そ の種類により異なっていることが影響しているものと 考えられ, ポリカルボン酸系高性能 $\mathrm{AE}$ 隇水剤の使用に より,ナフタレン系の高性能減水剤に比較して少ない添 加量で同等以上の分散効果が得られるものと考えられ $3^{5)}$.

\section{b)強度発現性}

圧縮強度試験結果を図-1に示す. 同図から分かるよう に, 各ケースの強度発現性は使用した結合材，および高 性能(AE)減水剂の種類により異っている.

まず，結合材の種類に着目すると，初期および長期の 強度発現の伸びに差がみられる. 三成分系セメントと普 通ポルトランドセメントを混合した配合 (1-1, 1-2) は, 材齢 28 日までの強度の増進が非常に大きくなっており, フライアッシュを混入した低熱ポルトランドセメント を使用した配合 (2-1，2-2) は，材跉初期の段階から非 常に絠やかに強度が増進している。この現象には, 各配 合の単位結合材量の $50 \%$ 以上を占める, ポルトランド セメントの種類の相違（普通または低熱），すなわち各 ポルトランドセメントの組成化合物の相違が大きく影 響しているものと考えられる.

次に, 高性能(AE)滅水剂の種類に着目すると, 同じ結 合材を使用した場合にポリカルボン酸系高性能 $\mathrm{AE}$ 減水 剤を使用した配合は,ナフタレン系の高性能减水剤を使 用した配合に比べ (1-2 と 1-1, および2-2 と 2-1 の比較), 材齢 28 日以降の強度が約 $9 \mathrm{~N} / \mathrm{mm}^{2}$ ほと高くなっている。 本実験結果は, 高性能(AE)減水剤の主成分の相違は強度
表-4 フレッシュコンクリート試験結果

\begin{tabular}{|c|c|c|c|}
\hline \multirow{2}{*}{$\begin{array}{l}\text { 配合 } \\
\text { No. }\end{array}$} & \multicolumn{3}{|c|}{ 測定項目 } \\
\hline & $\begin{array}{l}\text { スランプ } \\
\text { フロー }(\mathrm{cm})\end{array}$ & $\begin{array}{l}500 \mathrm{~mm} \text { フロー } \\
\text { 到達時間(秒) }\end{array}$ & $\begin{array}{c}\text { 充てん } \\
\text { 高さ }(\mathrm{cm})\end{array}$ \\
\hline $1-1$ & 67.5 & 6.1 & 36.5 \\
\hline $1-2$ & 72.5 & 3.3 & 37.0 \\
\hline $2-1$ & 70.5 & 7.1 & 36.0 \\
\hline $2-2$ & 69.0 & 4.0 & 37.0 \\
\hline
\end{tabular}

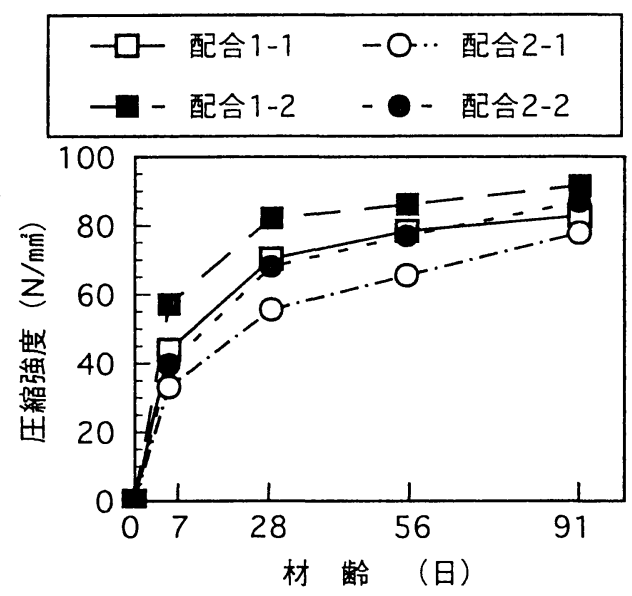

図-1 圧縮強度試験結果

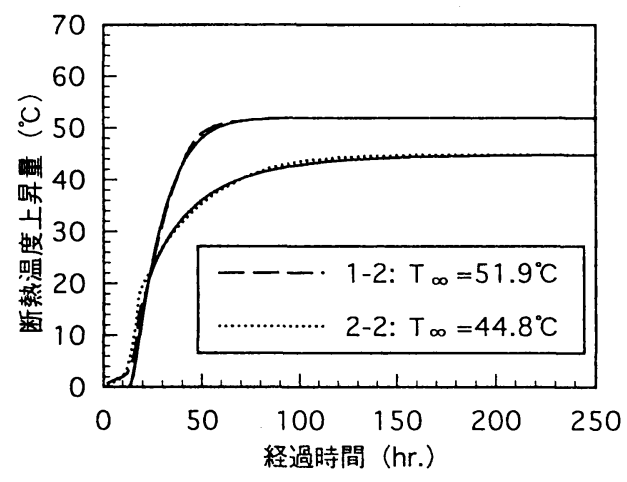

図-2 断熱温度上昇試験結果

発現性に若干の影響を及ほす可能性もあることを示唆 している5).

以上の結果より,ほとんどの配合において所要の強度 は得られたが, 高性能(AE)減水剤の種類の相違は, フレ ッシュコンクリートの品質に影響を及ぽすだけでなく, 硬化後の結合材の水和反応にも影響を及ぼすことが推 察された ${ }^{11)}$. 
表-5 コンクリートの仕様, 配合および使用材料

\begin{tabular}{|c|c|c|c|c|}
\hline $\begin{array}{c}\text { 配合強度 } \\
(\text { 材齡91日) }\end{array}$ & スランプフロー & $\begin{array}{c}500 \mathrm{~mm} \text { 7ロ- } \\
\text { 到達時間 }\end{array}$ & 空気量 & $\begin{array}{c}\text { 充てん高さ } \\
\text { (R2障害) }\end{array}$ \\
\hline $81 \mathrm{~N} / \mathrm{mm}^{2}$ & $65 \pm 5 \mathrm{~cm}$ & $3 \sim 8$ 秒 & $4 \pm 1 \%$ & $30 \mathrm{~cm}$ 以上 \\
\hline
\end{tabular}

\begin{tabular}{|c|c|c|c|c|c|c|c|c|c|c|c|c|}
\hline \multirow{3}{*}{$\begin{array}{l}\text { 配合 } \\
\text { No. }\end{array}$} & \multirow{3}{*}{$\begin{array}{l}G_{\max } \\
(\mathrm{mm})\end{array}$} & \multirow{3}{*}{$\begin{array}{l}\text { W/B } \\
\text { (\%) }\end{array}$} & \multirow{3}{*}{$\begin{array}{l}\text { s/a } \\
(\%)\end{array}$} & \multicolumn{9}{|c|}{ 単位量 $(\mathrm{kg} / \mathrm{m})$} \\
\hline & & & & \multirow{2}{*}{$\begin{array}{l}\text { 水 } \\
W\end{array}$} & \multicolumn{4}{|c|}{ 結合材 B } & \multirow{2}{*}{$S$} & \multirow{2}{*}{ G } & \multirow{2}{*}{$\begin{array}{c}\text { 高性能 } \\
A E \text { 減水郕 }\end{array}$} & \multirow{2}{*}{ 增粘㨈 } \\
\hline & & & & & $\mathrm{OBF}$ & $\mathrm{OP}$ & LP & $\mathrm{F}$ & & & & \\
\hline 1 & \multirow{2}{*}{20} & \multirow{2}{*}{30} & \multirow{2}{*}{45} & \multirow{2}{*}{165} & 350 & 200 & - & - & 704 & 899 & 11.0 & \multirow{2}{*}{0.5} \\
\hline 2 & & & & & - & - & 500 & 50 & 733 & 900 & 9.8 & \\
\hline
\end{tabular}

\begin{tabular}{|l|c|l|}
\hline 種類 & 記号 & \multicolumn{1}{|c|}{ 品 } \\
\hline 細骨材 & S & 君津産山砂,表乾比重2.58 \\
\hline 粗骨材 & G & 八戸産石灰砕石,表乾比重2.70 \\
\hline 高性能AE減水剤 & - & ポリカルボン酸系 \\
\hline
\end{tabular}

注）結合材，增粘剤については表-2に示す品質のものを使用した

\section{c)断熱温度上昇}

練上がり温度を $20^{\circ} \mathrm{C}$ とた，配合 1-2，2-2 の断熱温 度上昇試験の結果を図-2に示す. 図中に示した実線は, 実験結果を式（1）を用い近似させたものである。

$$
T(t)=T_{\infty}\left(1-\exp \left(-r\left(t-t_{0}\right)^{s}\right)\right)
$$

$\mathrm{T}(\mathrm{t})$ ：材齢 $\mathrm{t}$ 時間における断熱温度上昇量

$\mathrm{T}_{\infty}, \mathrm{r}, \mathrm{t}_{0}, \mathrm{~s}:$ 実験により定まる係数

$$
\begin{aligned}
& \mathrm{r}=0.027 \text { （配合 1-2），0.104（配合 2-2） } \\
& \mathrm{s}=1.263 \text { （配合 1-2），0.761（配合 2-2） }
\end{aligned}
$$

$\mathrm{t}_{0}$ は低熱夕イプの結合材ならびに高性能(AE)減水剤を 使用しているための, 初期の温度上昇の遅れを表現して おり,ここでは同バッチの試料で凝結試験を行って求め た凝結始発時間を $\mathrm{t}_{0}$ として用いた（1-2 は $124 \mathrm{hr}, 2-2$ は 12. lhr）。 $\mathrm{T}_{\infty}$ については, 同図に示す值を使用した.

結合材として低熱ポルトランドセメントを主に使用 した配合2-2 は，普通ポルトランドセメントを主な結合 材とした配合 $1-1$ に比べ，断熱温度上昇量は低く，発熱 速度もやや遅い結果となった。

図1に示した圧縮強度試験結果からも分かるように, 配合2-2で使用した低熱ポルトランドセメントは初期強 度が低く，長期の強度発現性が大きい.このことから， 結合材の水和反応か楥やかに進んだことか推察でき，同 配合の温度上昇特性からも明らかである．また，高強度 コンクリートに扔いては水和熱に起因する温度ひび割 れか懸念されるが,このような水和発熱特性を示す低熱 ポルトランドセメントを適用することは, その対策の一 つとして有効であるものと言える.
3. 高強度・高流動コンクリートの 地下連続壁模擬試験体への打設実験

\section{（1）実験内容}

\section{a)実験概要}

本実験では，前章で検討された二種類の高強度 ·高流 動コンクリートの地下連続壁への適用性を確認するこ とを目的に, 連続壁を模擬した試験体への打設実験を行 った，検討内容は，高酎力の地下連続壁の過密配筋状態 を模擬して配筋された型枠内へのコンクリートの充て ん性および硬化後の強度と密実度の評価等である。

\section{b)配合および使用材料}

本実験では, 使用結合材の異なる二種類の高強度 ·高 流動コンクリートを使用した. コンクリートの仕様, 配 合および使用材料を表-5に示す. 結合材は前章に示した 実験で使用したものと同等のものを用い, 配合 1 では三 成分系プレミックスセメント (OBF) と普通ポルトラ ンドセメントを組合せたものを, 配合 2 では低熱ポルト ランドセメントとフライアッシュを組合せたものを使 用した。

高流動性を付与するための混和剤として, 前章に示し た実験において高い強度が得られたポリカルボン酸系 高性能 $\mathrm{AE}$ 減水剂を使用した．また，分離抵抗性を高め， 品質の安定性を高めることを目的として多糖類ポリマ 一の増粘剤を使用した。

c)コンクリートの製造および運搬方法

コンクリートは, 市中のレディミクストコンクリート 工場において水平 2 軸式強制練りミキサ（練混ぜ容量 3 $\mathrm{m}^{3}$ )を使用して製造した. 1 バッチ当りの練混ぜ量を 1.5 


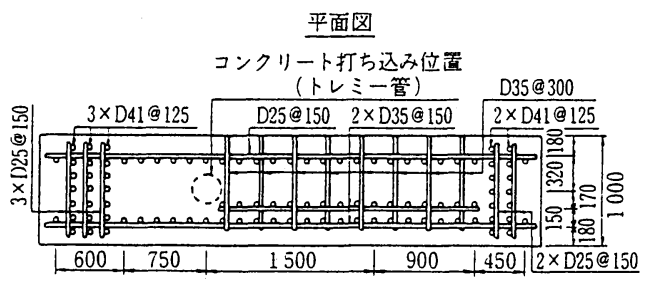

トレミー管 立面図

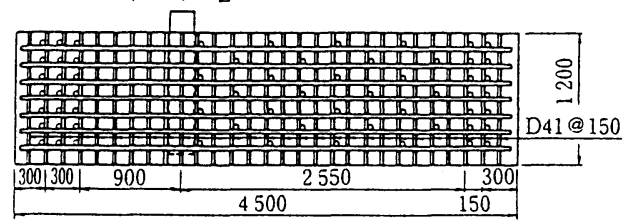

$(\mathrm{mm})$

図-3 試験体の形状・寸法および配筋状態

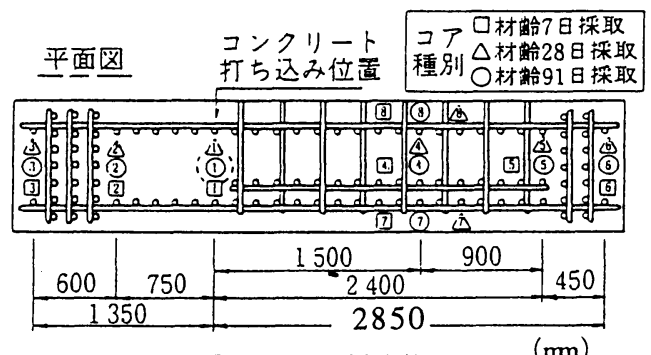

図-4 コア採取位置

$\mathrm{m}^{3}$ とし, 全材料を投入後 180 秒間練混ぜ, トラックアジ テータ車に排出した. トラックアジテータ車の積載量は 3 4.5 $\mathrm{m}^{3}$ とし, 1 試験体の打込み実験には 2 台のトラッ クアジテータ車のコンクリート $\left(7.5 \sim 9 \mathrm{~m}^{3}\right)$ を使用した.

トラックアジテータ車による打込み場所までの運搬 時間は 30 分程度であったが, 打込み前のコンクリート 品質試験や待機等の関係から, 練上がりから最長 100 分 程度までトラックアジテータ車のドラム内でアジテー トさせたものを試験体一打込んだ.

\section{d)コンクリートの打込み方法}

コンクリートを打込んだ試験体の形状・寸法およひ配 筋状况を図-3に示す.

ブーム付きコンクリートポンプ車により圧送された コンクリートを, トレミ一管を介して泥水 (ベントナイ

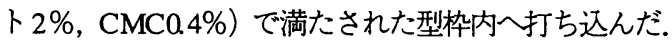
なお，コンクリートの圧送速度は $30 \mathrm{~m}^{3} / \mathrm{hr}$, 型枠内での コンクリートの打上がり速度は実構造物への打設速度 を想定して6〜 7m/hr とした.

\section{e)コンクリート打込み後の養生方法}

コンクリート打込み後の試験体は材齢 7 日までは外 気温（平均 $10^{\circ} \mathrm{C}$ )，7 日以降 28 日まではシートによる
表-6 打込み時の品質

(各配合共, トラックアジテータ車 2 台について 行った試験の平均値)

\begin{tabular}{|c|c|c|c|c|c|c|}
\hline \multirow{2}{*}{$\begin{array}{l}\text { 配合 } \\
\text { No. }\end{array}$} & \multicolumn{6}{|c|}{ 測定項目 } \\
\hline & $\begin{array}{l}\text { 和上がりからの } \\
\text { 䅅過時咸(分) }\end{array}$ & בタリート & $\begin{array}{l}\text { スランプ・ } \\
\text { 7a- }(\mathrm{cm})\end{array}$ & $\begin{array}{c}500 \mathrm{~mm} \text { 吅- } \\
\text { 到逵時间(秒) }\end{array}$ & $\begin{array}{l}\text { 充てん } \\
\text { 高さ }(\mathrm{cm})\end{array}$ & $\begin{array}{c}\text { 空気 } \\
(\%)\end{array}$ \\
\hline 1 & 55 & 21 & 67.0 & 4.1 & 35.0 & 4.5 \\
\hline 2 & 90 & 19 & 66.0 & 3.0 & 37.0 & 3.6 \\
\hline
\end{tabular}

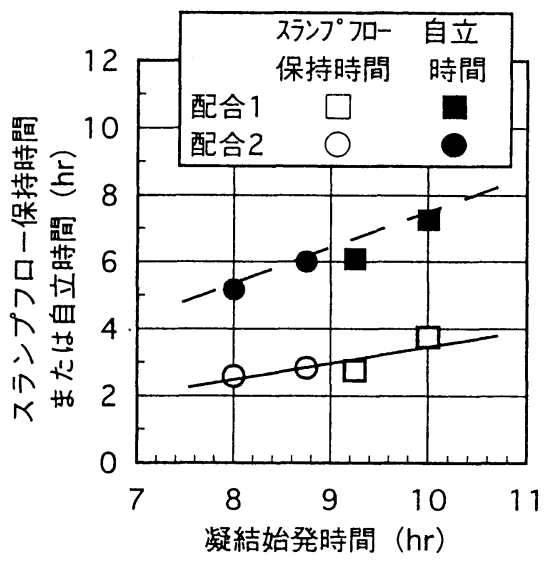

図-5 凝結始発時間とスランプフロー保持時間 および自立時間との関係

保温養生, 28 日以降は再び外気温 (平均 $7^{\circ} \mathrm{C}$ ) で養生し た.

f)打込みコンクリートの品質に関する試験項目

コンクリート出荷時, および打込み時にスランプフロ 一試験，空気量試験等を行い，また，圧縮強度試験用供 試体を採取した.なお，これらの試験は表-3に示す方法 に準じて行った。

g)試験体コンクリートの品質に関する試験項目

試験体コンクリートの品質は, 主に試験体から採取し たコア試料により評価した．打込み後，材齢 $7 ， 28 ， 91$ 日の時点で図4に示寸位置からコアを採取し, 圧縮強度, 単位容積質量を測定した。

（2）打込みコンクリートに関する実験結果

a)フレッシュコンクリートの品質

打込み時に実施した, フレッシュコンクリートの品質 管理試験結果を表-6に示す. 各配合共に, ほほ目標とし た品質のコンクリートが打ち込まれた。

b)スランプフロー経時変化と凝結特性

図5 は打込み時に採取したコンクリートについて, ス ランプフロー経時変化, 凝結時間を測定した結果をまと 
めたものである. 同図は, 凝結始発時間とスランプフロ 一が $50 \mathrm{~cm}$ 以下となる時間（以下，スランプフロー保持 時間と称す），およびスランプが $10 \mathrm{~cm}$ 以下となりコン クリートが自立するまでの時間（以下，自立時間と称 す）との関係を示した結果であるが, 結合材の種類に関 わらず各々一本の直線で示され，相関性か認められる.

また, 配合 1 に比べて配合 2 はやや自立時間が早い傾 向がみられ，その原因の一つとしては配合 2 の混和剤添 加量か配合 1 の場合に比べて少ないことが考えられる. 地下連続壁に用いる高流動コンクリートは, 施工性の面 から所要の流動性を一定時間保持する必要があるが, エ レメント継手部の接合鋼板等に作用する側圧は液圧で 作用するため，打込まれた後は速やかに流動性を失い， 自立することか望ましい.このような観点からは, 配合 1 に比べて配合 2 の方が適当な流動性の経時变化特性を 有しているものと考えられる.

\section{c)生縮強度}

図-6に打込み時に採取し，標準養生を行った供試体の 圧縮強度試験結果を示す。どちらの配合も配合強度 $81 \mathrm{~N} / \mathrm{mm}^{2}$ 満たす結果となっている. また, 結合材とし て三成分系プレミックスセメントと普通ポルトランド セメントを組合せた配合 1 に比べ, 低熱ポルトランドセ メントとフライアッシュを組合せた配合 2 は長期材齢 での強度増進が大きい傾向にあり, 前章の配合選定実験 における結果と同様の傾向がみられた。

（3）試験体コンクリートに関する実験結果

\section{a)試験体の温度上昇}

コンクリート打込み後の, 試験体中央部の温度測定結 果を図7に示す.

主な結合材として低熱ポルトランドセメントを使用 した配合 2 は, 三成分系プレミックスセメントと普通ポ ルトランドセメントを組合せた配合 1 に比べて最高温 度が低く, $15^{\circ} \mathrm{C}$ 程度の差がみられた.これは, 図-2に示 すような各配合の断熱温度上昇特性が影響したものと 考えられる.

\section{b)試験体のコア強度}

試験体の図-4に示す位置において, 鉛直方向に一括ボ ーリングしてコアを採取した後，上部，中部，および下 部 (各々試験体底面から 80 100 cm, 50 70 cm, 10 30 $\mathrm{cm}$ の位置) とに分けて強度試験を行ったが, 上中下のコ ア強度差に一定の傾向がみられなかったため, ここでは 上中下の測定値を平均した強度を, そのボーリング位置 でのコア強度として整理した. また, コンクリート流動 時の鉄筋の有無が圧縮強度に及ばす影響を検討するた め,コア採取位置に応じて場合分けを行い, 各位置のコ ア強度の平均值を求めて, 各場合のコア強度としてまと めた。

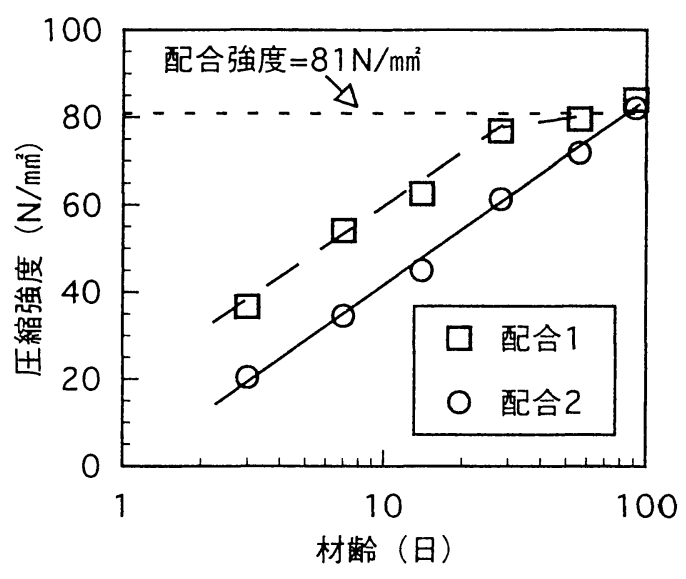

図-6＼cjkstart標準養生供試体の圧縮強度

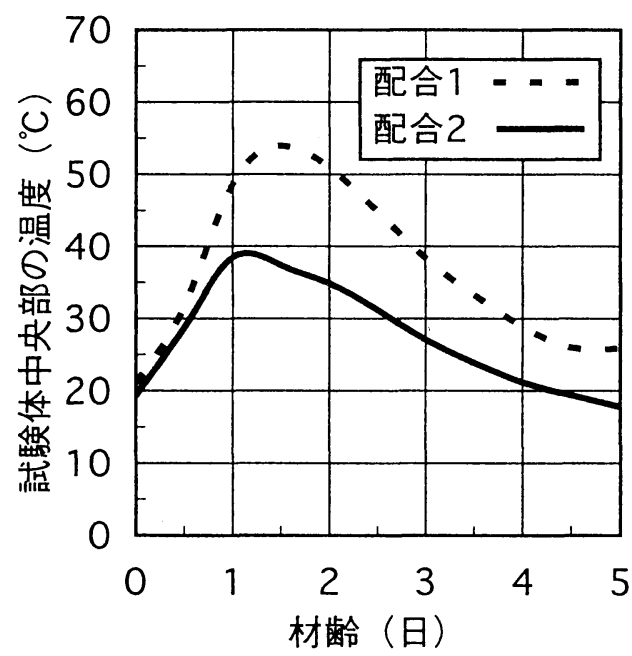

図-7 試験体中央部の温度測定結果

したがって, 図8に示すコアの圧縮強度試験結果は, 以下に示寸四つの場合分けに従って, 表示したものであ る. 打込み位置(1)に対して，(2)，(4)，(5)から採取された コアはコンクリートが流動した時に過密配筋の影響を 受けない場合とした. これに対して(3)，6はそれぞれ3 段，2段の過密配筋を流れ越した場合である.さらに， (7), 8)はコンクリートの流動方向に対して側方にある格 子配筋の影響を受けた場合である.

各々の配合において, 過密配筋の影響を受けない位置 (2)，(4)，(5)）と打込み位置とで比較すると, 強度は同 等であり, 流動による強度低下は認められない.これに 対し, 配合 1 においては過密配筋部を流れ越した場合, および格子配筋の影響を受けた場合には強度低下がみ られた ${ }^{6)}$. また, その強度低下の影響度は流動方向の側 

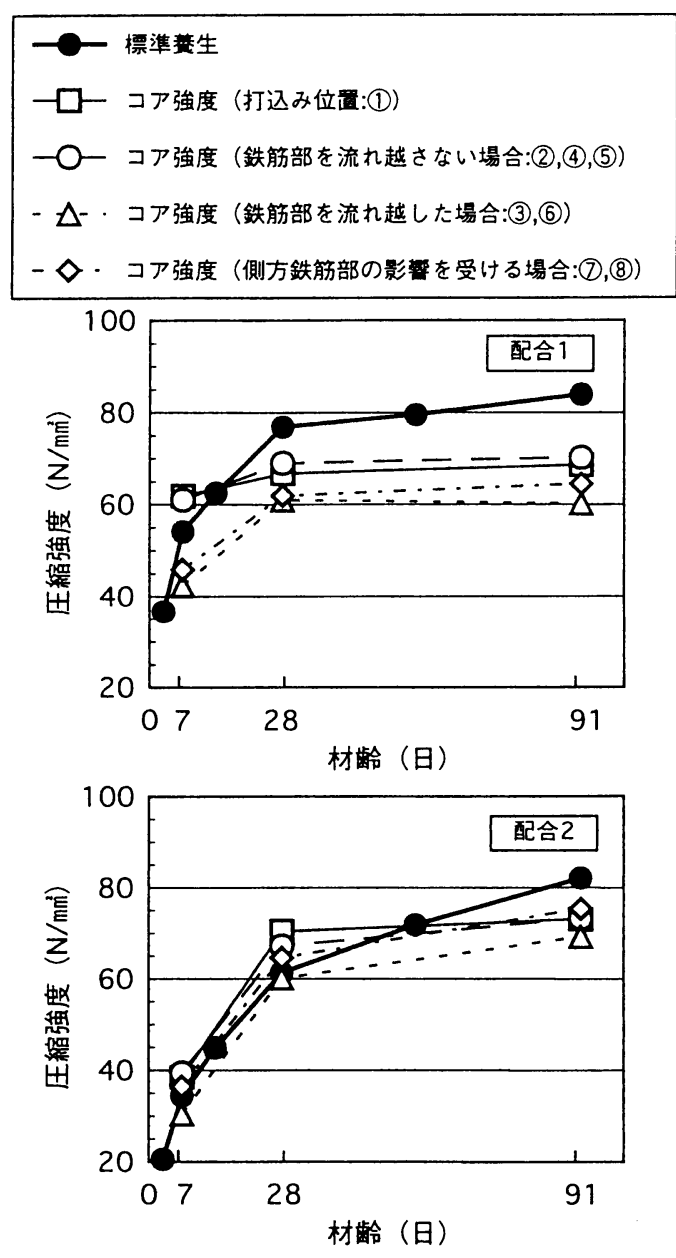

困-8コアの圧縮強度試験結果

方に配置された格子鉄筋に比べ，2段あるいは３段過密 配筋の方が大きい傾向がみられた，さらに，配合1では 標準養生供試体の発現状況と異なり，材齢 28 日以降の 強度増進が極めて小さい傾向にある。

これに対し, 配合 2 では流動時における鉄筋部の流れ 越しによる影響はほとんど認められず，また，標準養生 供試体とほほ同等の強度発現性を示した。

以上の結果から, 配合 2 については流動時の鉄筋部障 害の影響をほとんど受けず, 試験体全体にわたって均等 な強度が得られていることが確認された。

\section{c)形責算温度によるコア強度の評価}

図-8に示すように,配合1ではコアの採取位置に関わ らず，材齢 28 日以降の長期強度の増進が得られなかっ た.この原因として, コンクリートの硬化初期に高温履 歴を受けたことが考えられる. そこで, 温度履歷の影響 を検討するために, 強度の発現状況を積算温度で表現し た結果を図-9に示す。

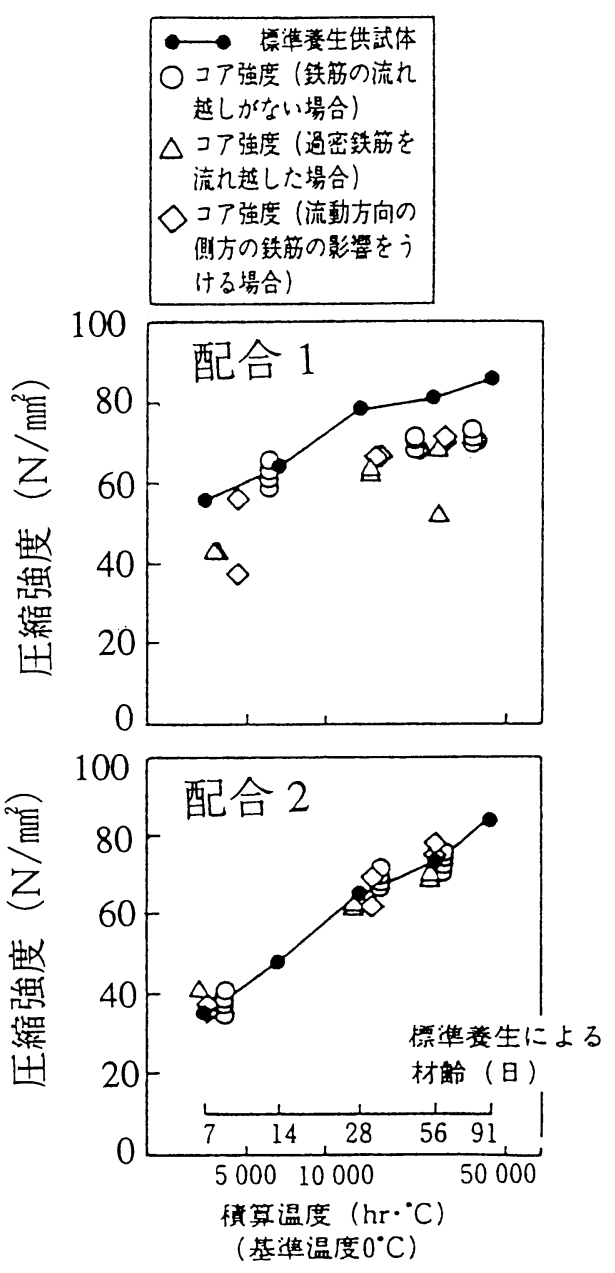

図-9＼cjkstart積算温度で表現したコア強度の発現状況

配合 2 では，材齢28 日まではコア強度の発現状況が 標準養生供試体の強度発現履歴と同等以上である.これ は, 図7に示すように硬化初期の温度履歷か配合 1 に比 べて緩やかであり，その後も標準養生と同等な温度履歴 を経たことが影響しているものと考えられる。

これに対して, 配合 1 では初期材齢の段階から両者は 異なった履歴を示している.この現象は, 図7に示す配 合 1 の材㱓 1 2 日の水和発熱による高温状態が, 本来 は積算温度で表現できるはずの通常のポルトランドセ メントとの水和反応に影響を及ほしたことや, 材龄が释 過しても硬化体中の細孔容積量がほとんど減少しなく なるなど, 長期的に安定して強度が発現しない組織構造 を生じさせたことが要因として考えられる12)。

d)コアの単位容積質量

材齢 91 日のコア供試体の単位容積質量の測定結果を, 図-10に示す。なお，同図には先のコア強度試験結果と 同様に, 各コア採取位置の高さ方向の平均值を示した. 最も過密配筋部の影響を受け易いと思われた(3)および 


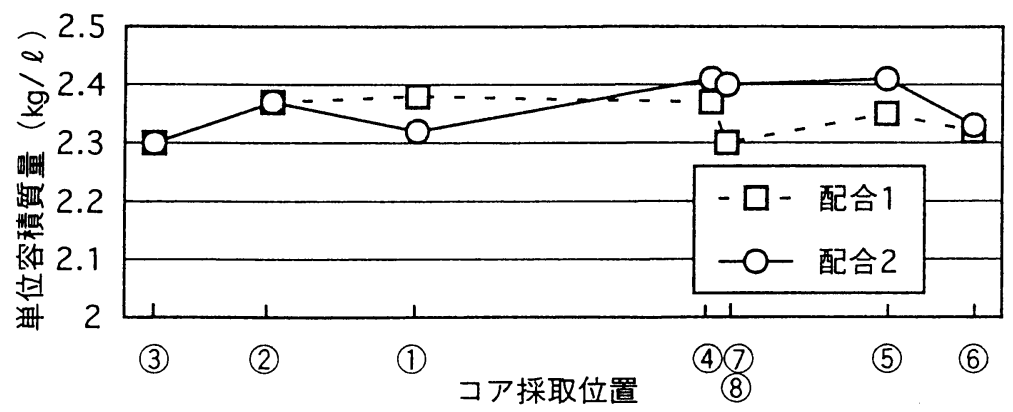

図-10 コア供試体の単位容積質量測定結果

６の位置において，単位容積質量はいずれの配合につい てもやや低下しているが,これらの位置以外については 打込み位置の単位容積質量とほほ同等の試験結果が得 られている.この結果から, 本試験体の全体にわたり骨 材はほほ均等に分布していることが分かる.

\section{4. 高強度・高流動コンクリートの 実規模地下連続壁における性能実証実験}

\section{（1）実験内容}

\section{a)実験概要}

第3 章に示した打設実験において, 低熱ポルトランド セメントを主な結合材として使用した高強度・高流動コ ンクリート配合は, 硬化時の温度上昇が低いため, 打込 みコンクリートの強度発現性が良好であり, 鉄笳部を流 れ越した場合の強度低下がほとんど認められなかった。

このような実験秸果を受け, 本実験では同配合を用いて 実大規模の地下連続壁へ適用することにより，同配合の 市中のレディミクストコンクリート工場における連続 製造の可能性, コンクリート構造体の硬化後の品質等を 確認することとした.

本実験で対象とした部材は，幅 $8 \mathrm{~m}$, 壁厚 $1 \mathrm{~m}$, 深度 $50 \mathrm{~m}$ の実大規模の地下連続壁である. 配筋状況は図-11

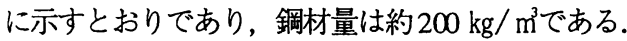

\section{b)配合およひ使用材料}

実験に用いたコンクリートの仕様，配合および使用材 料を表-7に示す. 第3 章に示した実験結果から,コンク リートの配合強度を $81 \mathrm{~N} / \mathrm{mm}^{2}$ ，水結合材比を $30 \%$ とした。 本実験では第 $2 ， 3$ 章に示した実験と同様に，結合材と して低熱ポルトランドセメントとフライアッシュを使 用したが, レディミクストコンクリート工場における製 造の容易性等を考慮して, これらの結合材を同様の比率 で事前に混合したプレミックス品(フライアッシュ混入 率9％）を使用した.

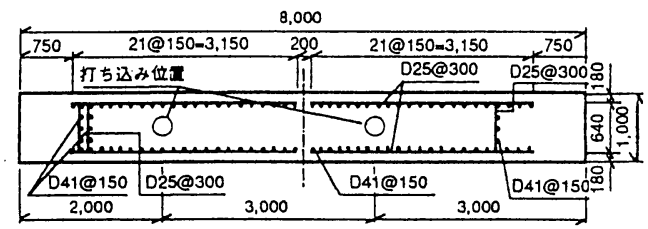

(mm)

図-11 地下連続壁の形状・寸法および配筋図

表-7 コンクリートの仕様, 配合および使用材料

\begin{tabular}{|c|c|c|c|c|c|c|c|c|c|}
\hline \multicolumn{2}{|c|}{$\begin{array}{c}\text { 配合強度 } \\
(\text { (材柃91日) }\end{array}$} & \multicolumn{2}{|c|}{$\begin{array}{c}\text { スランプ } \\
\text { フロー }\end{array}$} & \multicolumn{2}{|c|}{$\begin{array}{l}500 \mathrm{~mm} \text { 听 } \\
\text { 到達時間 }\end{array}$} & \multicolumn{2}{|c|}{ 空気量 } & \multicolumn{2}{|c|}{$\begin{array}{l}\text { 充てん高さ } \\
\text { (R2障害) }\end{array}$} \\
\hline \multicolumn{2}{|c|}{$81 \mathrm{~N} / \mathrm{mm}$} & \multicolumn{2}{|c|}{$65 \pm 5 \mathrm{~cm}$} & \multicolumn{2}{|c|}{ 3〜10秒 } & \multicolumn{2}{|c|}{$4 \pm 1 \%$} & \multicolumn{2}{|c|}{$30 \mathrm{~cm}$ 以上 } \\
\hline \multirow{2}{*}{$\begin{array}{l}G_{\max } \\
(\mathrm{mm})\end{array}$} & \multirow{2}{*}{$\begin{array}{l}\text { W/B } \\
(\%)\end{array}$} & \multirow{2}{*}{$\begin{array}{l}\text { s/a } \\
(\%)\end{array}$} & \multicolumn{7}{|c|}{ 単位量 $\left(\mathrm{kg} / \mathrm{m}^{\prime}\right)$} \\
\hline & & & $\begin{array}{l}\text { 水 } \\
w\end{array}$ & $\begin{array}{c}\text { 結合材 } \\
\text { B }\end{array}$ & S1 & S2 & G & SP & BP \\
\hline 20 & 30 & 52 & 168 & 560 & 579 & 248 & 793 & 13.2 & 0.5 \\
\hline
\end{tabular}

\begin{tabular}{|c|c|c|}
\hline 種 類 & 記号 & 品 \\
\hline 結合材 & B & 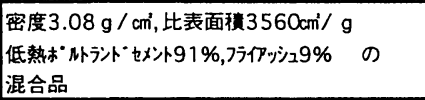 \\
\hline \multirow{2}{*}{ 細骨材 } & S1 & 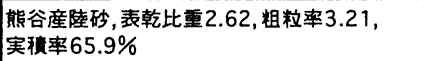 \\
\hline & S2 & 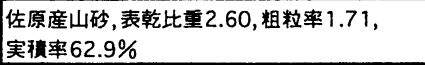 \\
\hline 粗骨材 & G & 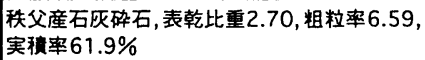 \\
\hline $\begin{array}{c}\text { 高性能 } \\
\mathrm{AE} \text { 減水郕 }\end{array}$ & SP & $\begin{array}{l}\text { ポリカルボン酸エーテル系と架挢ボリマーの } \\
\text { 複合体 }\end{array}$ \\
\hline 增粘浏 & BP & 多糖類ボリマー \\
\hline
\end{tabular}

c)コンクリートの製造および運搬方法

コンクリートは, 市中のレディミクストコンクリート 工場において水平 2 軸式強制練りミキサ（練混ぜ容量 3 $\left.\mathrm{m}^{3}\right)$ を使用して製造した. 1 バッチ当りの練混ぜ量を 2.25 $\mathrm{m}^{3}$ とし，練混せ時間は 180 秒（モルタル先練り 80 秒， 粗骨材投入後 100 秒) とした．また，製造時には全製造 バッチについてモニターカメラによる練混ぜ状態の目 視確認，ならびにミキサ負荷値の確認を行った。 


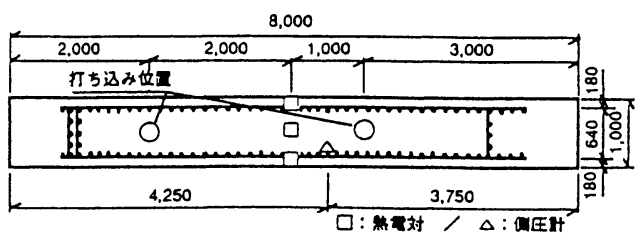

$(\mathrm{mm})$

図-12 計測器配置図

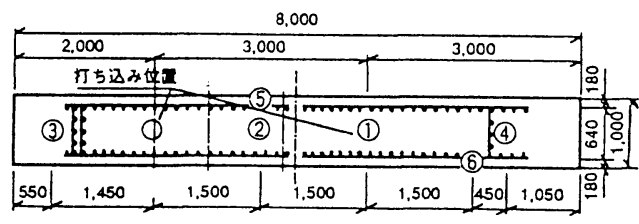

$(\mathrm{mm})$

図-13 コアボーリング位置図（1)（6)

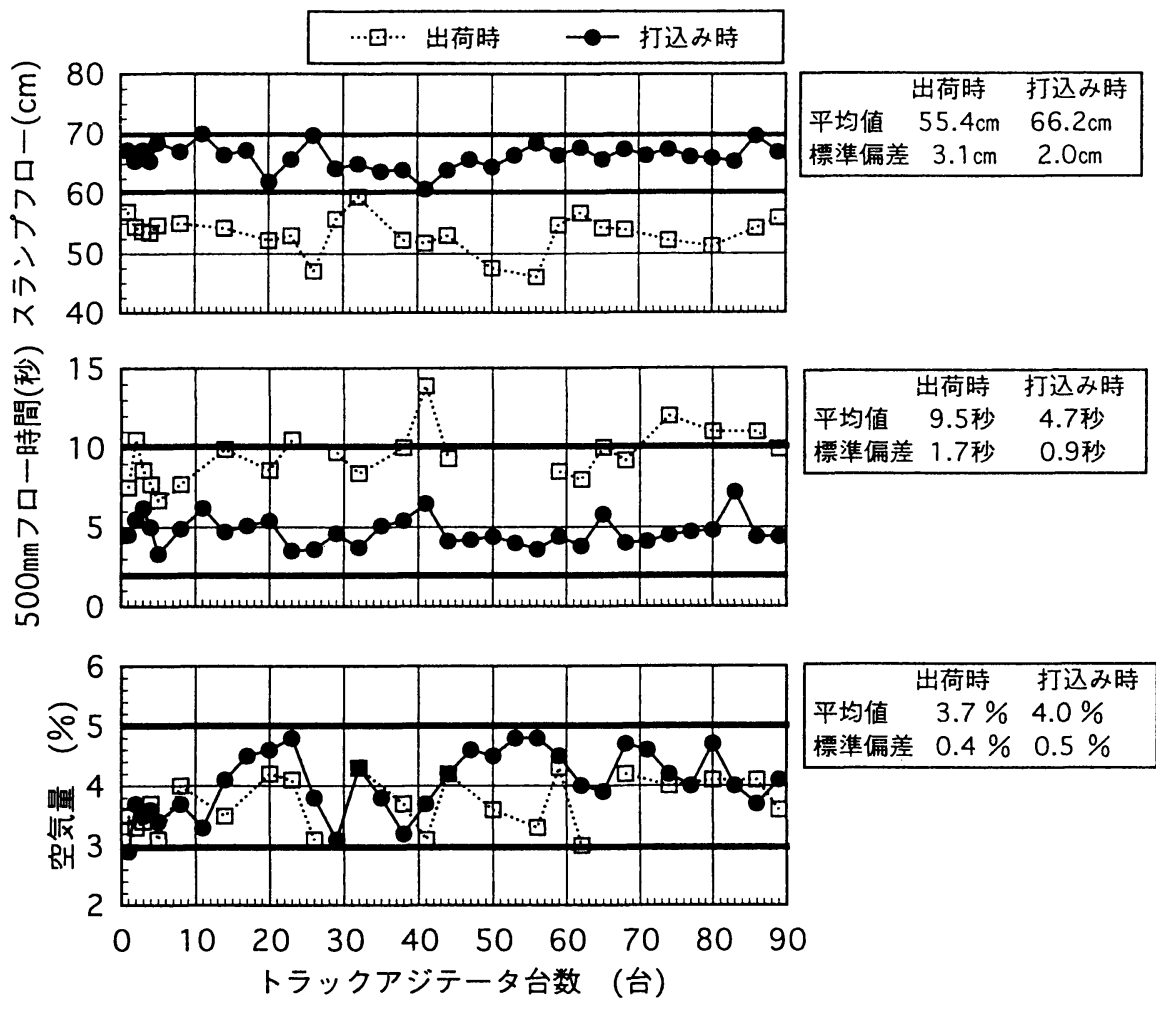

図-14 フレッシュコンクリート品質管理試験結果

トラックアジテータ車の積載量は $4.5 \mathrm{~m}^{3} /$ 台, コンクリ 一トの製造・出荷量は $40 \mathrm{~m}^{3} / \mathrm{hr}$ 程度とし, 総打設量は $410 \mathrm{~m}^{3}$ であった. また, トラックアジテータ車による打 込み場所までの運搬時間は約 40 分であった.

d)コンクリートの打込み方法

ベントナイト系の安定液（ベントナイト $2 \%$, $\mathrm{CMC} 0.4 \%)$ が満たされた連壁溝に 2 本のトレミー管 ( $\phi$ $250 \mathrm{~mm} \times 3 \mathrm{~m})$ を図11 に示卞位置に設置し，トラックア ジテータ車のシュートから両方のトレミー管へコンク リートを直接流し込んで打込んだ. なお，トレミ一管の コンクリートへの根入れ深さは $2 \sim 6 \mathrm{~m}$ とし，管の切り 継ざ時以外は連続的にコンクリートを打設した. 平均の 打上がり高さは $5 \mathrm{~m} / \mathrm{hr}$ であった. e)打込みコンクリートの品質試験方法

コンクリート出荷時, およひ現場打込み時にはスラン プフロー試験, 空気量試験等を表-3に示す方法に準じて 行った.

f)打込み時の計則項目・方法

構造体には, 図-12 に示す位置に計測器を埋設した。 深度- $44 \mathrm{~m}$ から- $14 \mathrm{~m}$ まで $5 \mathrm{~m}$ 間隔で側圧計を設置し，コ ンクリートの側圧を測定した．また，深度-25m の位置 に熱電対を設置し，構造体の温度を測定した。

g)構造体コンクリートの品質確認方法

構造体コンクリートの品質は, 構造体からコアボーリ ングして採取されたコア供試体により確認した。コアボ ーリングを行った位置を図13に示す。なお，(1)，(2)の 位置については深度-50m 程度までコアを採取できたが, 


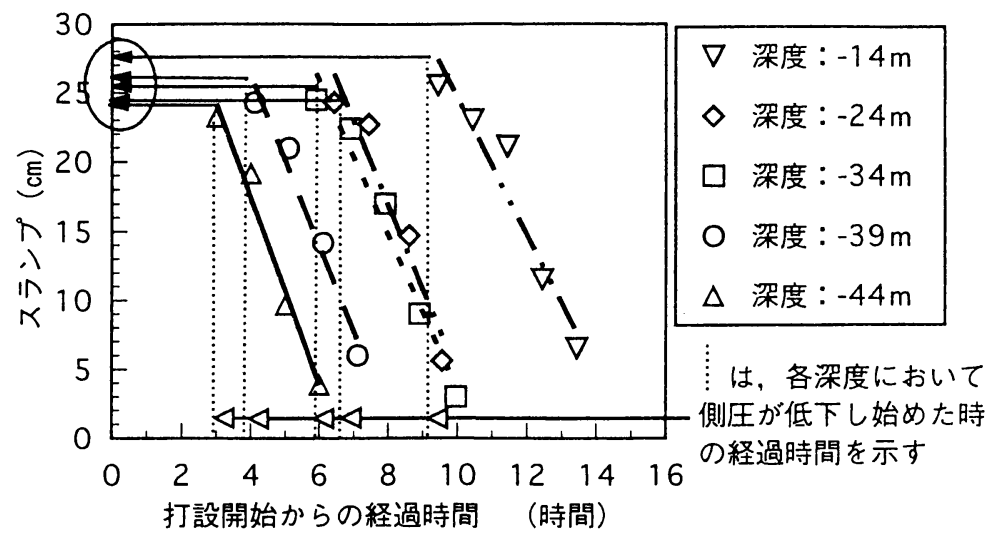

図-15 スランプ経時変化測定結果

他の位置についてはボーリング時の曲がりのため, 深度 -10m〜-45m 程度までの採取となった.

コアの採取は材龄58 日から91日において実施し，材 齢91日において圧縮強度, 単位容積質量を測定した。

（2）打込みコンクリートに関する実験結果

a)フレッシュコンクリートの品質

工場出荷時および打込み時における, コンクリートの 品質管理試験結果を図-14亿示す. 出荷時のスランプフ ロー平均值 $55.4 \mathrm{~cm}$ に対し, 打込み時のスランプフロー 平均値は $66.2 \mathrm{~cm}$ であり, $10 \mathrm{~cm}$ 程度の差がみられるが, これは架橋ポリマーか配合された高性能 $\mathrm{AE}$ 減水剤を使 用したためである。また，U形充てん装置による間げき 通過性試験を打込み時に行ったが, 充てん高さはどの場 合においても $36 \mathrm{~cm}$ 程度であった.

打込み時のスランプフローや $500 \mathrm{~mm}$ フロー到達時間 の標準偏差は小さいことから, 品質の安定したコンクリ 一トが製造・施工されたものと考えられる.

b)スランプフローの保持時間と側厓

打込み時においては，図-15 に示す深度別に試料を採 取し，スランプ (フロー) の経時変化を調べ，打込みコ ンクリートの流動性の損失と連壁内に設置した側圧計 による側圧の低下との関係を調べた。

平均の打上がり速度は $5 \mathrm{~m} / \mathrm{hr}$ であったが, 側圧は発生 からおよそ 2 時間程度でピークとなり，その值は 10〜 $12 \mathrm{t} / \mathrm{m}^{2}$ であった．図-15 は，側圧低下時の経時変化測定 用試料のスランプ (静置状態で練置き) を示したもので あるが，いずれの梁度においてもスランプが $25 \mathrm{~cm}$ 程度 になると，側圧は低下する傾向がみられる7)。したがっ て, 打込みコンクリートのスランプ (フロー) 経時変化 を調べることは, 有効な側圧管理手法になるものと考え られ，スランプ $25 \mathrm{~cm}$ 程度が側圧低下の目安になるもの と考えられる.
表-8 標準養生供試体の圧縮強度試験結果

\begin{tabular}{|c|c|c|c|c|}
\hline 材齡 & 甘ンプル数 & $\begin{array}{l}\text { 平均值 } \\
\left(\mathrm{N} / \mathrm{mm}^{2}\right)\end{array}$ & $\begin{array}{c}\text { 標準偏差 } \\
\left(\mathrm{N} / \mathrm{mm}^{2}\right)\end{array}$ & $\begin{array}{c}\text { 変動係数 } \\
(\%)\end{array}$ \\
\hline 3日 & 5 & 21.3 & 2.9 & 13.9 \\
\hline 7日 & 10 & 35.5 & 3.5 & 9.9 \\
\hline 14日 & 5 & 48.2 & 4.9 & 10.2 \\
\hline 28日 & 10 & 61.3 & 5.8 & 9.4 \\
\hline 56日 & 5 & 68.3 & 4.7 & 6.8 \\
\hline 91日 & 10 & 81.7 & 3.5 & 4.3 \\
\hline
\end{tabular}

\section{c)压縮強度}

打込み時に採取した, 標準養生供試体の圧樎強度試験 結果を表-8に示す.初期材齢において変動係数は比較的 大きいが, 材齢を経るに従い小さくなる傾向がみられる. 材龄 91 日の圧縮強度は $82 \mathrm{~N} / \mathrm{mm}^{2}$ 程度であり, 目標の配合 強度を満足している。

\section{（3）構造体コンクリートに関する実験結果}

\section{a)搆造体の温度履歴}

埋設した熱電対により連壁内の温度を測定した結果, 連壁中央部はコンクリート打込み後, およそ2 日で最大 温度を示しており，最大温度は $48.2^{\circ} \mathrm{C}$, 温度上昇量はお よそ30Cであった。

\section{b)煹造体のコア強度}

構造体から採取されたコアの強度についでは, 各採取 位置における高さ方向のばらつきはほとんどみられず, 材齢 91 日における構造体全体の平均強度は $820 \mathrm{~N} / \mathrm{mm}^{2}$, 標準偏差 $5.7 \mathrm{~N} / \mathrm{mm}^{2}$, 変動係数 $7.0 \%$ であった ${ }^{8)}$. 打込み 時に採取した標隼養生供試体の同材齢における圧縮強 度平均値は, 表-8に示すようにこれと同等であったこと から, 構造体における平均強度としては標準養生供試体 と同等の品質が確保されたが, 構造体強度の変動係数は やや増加する傾向がみられた。 


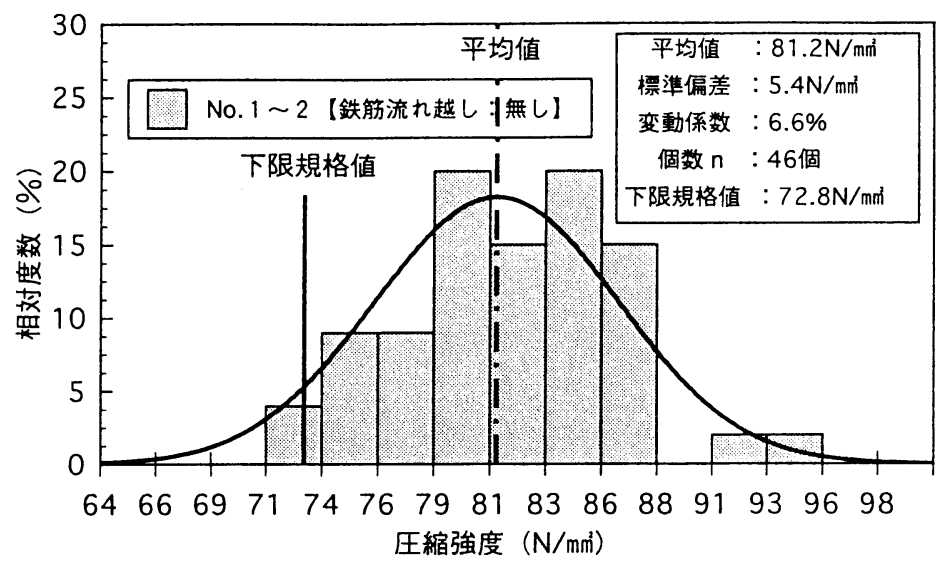

図-16コア供試体の圧縮強度分布（鉄筋部の流れ越しが無い場合）

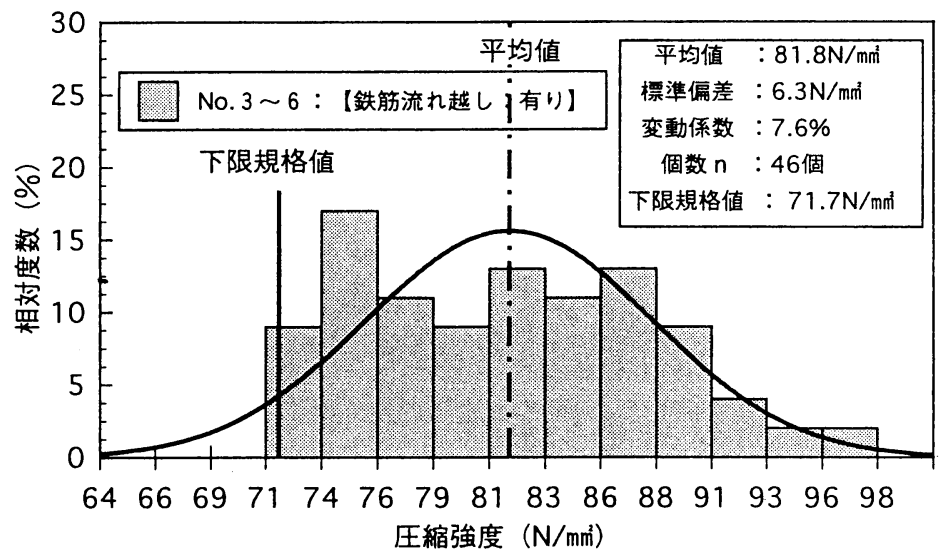

図-17コア供試体の圧縮強度分布（鉄筋部の流れ越しが有る場合）

次に, 構造体から採取したコア供試体を鉄筋部の流れ 越しの影響が無い部分 (1), (2)），および鉄筋部の流れ 越しの影響が有る部分 (3) (6) とに区別し，各々の圧 縮強度分布を図-16，17に示す．なお，両図には強度の 測定值か正規分布に従うと仮定した場合の, 正規分布に おける 5\%不良確率を下限規格值として示した。

鉄筋部の流れ越しの影響の無い部分の平均強度は $81.2 \mathrm{~N} / \mathrm{mm}^{2}$, 標準偏差 $5.4 \mathrm{~N} / \mathrm{mm}^{2}$, 変動係数 $6.6 \%$ であり, 標準養生供試体に対して平均強度に差はみられないが, 変動係数はやや増加している. 盖生条件の相違や, 供試 体の作製方法 (コアおよび標準供試体) がこれらの結果 に影響したことも考えられるが, 安定液中への打設に伴 う品質の低下はわずかにあったものと考えられる.

さらに, 鉄筋部の流れ越しの影響の有る部分の平均強 度は $81.8 \mathrm{~N} / \mathrm{mm}^{2}$, 標隼偏差 $6.3 \mathrm{~N} / \mathrm{mnn}^{2}$, 変動係数 $7.6 \%$ であ り，流れ越しの影響の無い場合に対して平均強度に差は
みられないが, 変動係数はやや増している.このことか ら, 鉄筋部をコンクリートが流れ越すことによっても品 質の変動はやや増加する傾向がみられた。

以上の結果を基に，本実験で用いた高強度·高流動コ ンクリートを地下連続壁へ適用する場合の, 配合強度の 算定方法を以下に提案する.

すなわち，一般にコンクリートの配合強度において考 慮されるコンクリート製造時の変動に伴う割増し係数 （ $\alpha ）$ の他に, 安定液中への打設に伴う品質変動，およ び鉄筋部の流れ越しに伴う品質変動を考慮した割増し

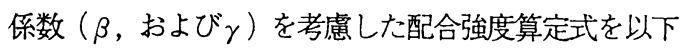
に示す.

$$
\mathrm{f}^{\prime} \mathrm{cr}=\mathrm{f}^{\prime} \mathrm{ck} \times \alpha \times \beta \times \gamma
$$

$\mathrm{f}^{\prime} \mathrm{cr}$ ：配合強度 
$\mathrm{f}^{\prime} \mathrm{ck}$ ：設計基準強度

$\alpha:$ 製造時の変動に関わる割増し係数

$\beta:$ 安定液中に打込むことによる

品質変動を考慮した割増し係数

$\gamma:$ 鉄筋部の流れ越しに伴う品質変動を

考慮した割增し係数

本実験秸果から，各割増し係数を試算すると，打込み 時に採取した標準養生供試体の変動係数が $4.3 \%$ \%゙あっ たことから，参考文献 ${ }^{13)}$ に示される割増し係数算定式

(割增し係数 $=1 /\left(1-1.64 / 100^{*}\right.$ 変動係数) ) より $\alpha$ は 1.08 となる，さらに，標準養生供試体の変動係数に対する鉄 筋部の流れ越しの影響の無い場合 (安定液中への打設の 影響）の変動係数増分 $2.3 \%$ から $\beta$ は 1.04 ，流れ越しの 影響の無い場合に対する流れ越しの影響の有る場合の 変動係数増分 $1.0 \%$ から $\gamma$ は 1.02 となる.これより,コ ンクリート製造時の変動に伴う割増し係数に比べ，安定 液中への打設や鉄筋部の流れ越しに伴う品質変動を考 慮した割増し保数は小さいことが分かる。

なお，地下連続壁に用いられる一般のコンクリートに おける安定液中での強度低滅比 $(=1 /(\beta \times \gamma))$ は, 通常 $0.8 \sim 0.9$ 程度を見込んでいる ${ }^{14)}$.これに対して本実験 で用いた高強度・高流動コンクリートの場合には， 0.94 $(=1 /(1.04 \times 1.02))$ 程度の強度低減比を見込めば良いと 言える.

\section{C)煹造体の単位容積質量}

構造体から採取されたコアの単位容積質量は 2.42 $\mathrm{t} / \mathrm{m}^{3}$ 程度であり，各採取位置における高さ方向のばらつ きや, 各採取位置における変動はほとんと認められなか ったことから，鉄筋部の流れ越しによる粗骨材の分離は ほとんどなかったものと考えられる8)。

\section{5. まとめ}

本研究では，地下連続壁を対象とした配合強度 80 $\mathrm{N} / \mathrm{mm}^{2}$ 以上の高強度・高流動コンクリートの配合を検討 し，地下連続壁を模擬した試験体，および実大規模の地 下連続壁への打設害験を行った. 得られた知見を以下に まとめる。

（1）高強度·高流動コンクリートの配合設計において は, 流動性, 分離抵抗性等のフレッシュ時の性能, およ び強度特性や硬化時の発熱特性等, これら所要の性能に 応じて, 使用する結合材や高性能(AE)減水剤の種類およ び組合せを適切に選定することが必要であり，本研究の 範囲では低熱ポルトランドセメントを主体とした結合 材とポリカルボン酸系高性能 $\mathrm{AE}$ 減水剂を使用した配合 は所要のフレッシュ時の性能を満足し, 硬化時の温度上 昇量が小さく，長期の強度発現性が良好であった。
（2）本研究で選定した高強度・高流動コンクリートは, 一般のレディミクストコンクリート工場においても連 続的に安定した品質のものが製造可能であり, 通常の連 壁コンクリートと同様にトレミー工法による打込みが 可能であった.

（3）側圧低下時の打込みコンクリートのスランプは, 打設深度に関わらずほほ $25 \mathrm{~cm}$ 程度であったことから， 打込みコンクリートのスランプ (フロー) 経時変化を調 べることは, 有効な側圧管理手法になるものと考えられ 側圧発生から低下し始めるまでの時間の制御は, スラン プフロー経時変化特性の制御により行えるものと考え られる。

（4）本研究で選定した高強度·高流動コンクリートを 打込んだ構造体の強度は，打込み時に採取した標準盖生 供試体とほほ同等の強度を有したが, その変動係数はや や増加する傾向がみられた. したがって, 本コンクリー 卜の配合強度の算定においては, コンクリート製造時の 変動に伴う割増し係数の他に, 安定液中への打設に伴う 品質変動, および鉄筋部の流れ越しに伴う品質変動を考 慮した割増し係数も考慮する必要があるものと考えら れる. 本実験の結果からこれらを算定すると，製造時の 変動に伴う割增し係数は 1.08 , 安定液中への打設に伴う 品質変動を考慮した割増し係数は 1.04 , および鉄筋部の 流れ越しに伴う品質変動を考慮した割增し係数は 1.02 となる.

謝辞：本研究を遂行するにあたり，コンクリートの製造 にはアサノコンクリート株式会社横浜工場, ならびに旧 秩父生コン株式会社浦和工場の皆様，また，コンクリー トの品質管理にあたっては旧秩父セメント株式会社, ポ ゾリス物産株式会社の皆椂に多大な御協力を頂きまし た. 関係者各位に厚くお礼申し上げます。

\section{参考文献}

1) 三浦律彦, 峯岸孝二, 関晃一, 岩井稔: 高ビーライトセメ ントの高強度地下連続壁コンクリートへの適用性に関す る基䃈的研究，コンクリート工学年次論文報告集, Vol.16, No.1, pp.271-276, 1994.

2）大友忠典, 田沢雄二郎, 村田俊彦, 馬場英二郎: 高性能地 下連続壁のコンクリートの実大規模実証実験, コンクリー 卜工学年次論文報告集, Vol.16, No.1, pp.1239-1244, 1994.

3）今井実, 田中秀輝：地下連続壁用高強度コンクリートに関 する基礎的研究，土木学会第 49 回年次学術講演会講演概 要集, Vol.49, pp.1040-1041, 1994.

4）高木貞人：特集 大深度掘削-最近の動向と事例集 事例 集（2）LNG, LPG 地下タンクの例, 基礎工; Vol.18, No.7, pp.33-40, 1990. 
5）新藤竹文, 大友健, 横田和直, 坂本淳 : 高強度性を有する 超流動コンクリートの配合選定実験，土木学会第 48 回年 次学術講寅会講演概要集 V, Vol.48, pp. 150-151, 1993.

6）大友健, 横田和直, 坂本淳, 松岡康訓：高強度·超流動性 連続地中壁コンクリートの充填性実験，土木学会第 48 回 年次学術講演会講演概要集 V, Vol.48, pp.72-73, 1993.

7）松岡康訓, 大友健, 横田和直, 坂本淳: 高強度·超流動性 連続地中壁コンクリートの実用性実証実験，土木学会第 48 回年次学術講演会講演概要集 V, Vol.48, pp.152-153, 1993.

8）横井謙二, 松岡康訓, 横田和直, 坂本淳: 高強度·高流動 地下連続壁コンクリートの構造体強度, 土木学会第 49 回 年次学術講演会講演概要集 V, Vol.49, pp.376-377, 1994.

9）新藤竹文, 大友健, 横田和直, 坂本淳: 高強度·高流動地 下連続壁コンクリートの硬化物性, 土木学会第 49 回年次 学術講演会講演概要集 $V$, Vol.49, pp.228-229, 1994.

10) 土木学会 コンクリート委員会 高流動コンクリート指 針作成小委員会編：高流動コンクリート施工指針，コン クリートライブラリー93, pp.157-176,1998.
11）青木茂, 十河茂幸, 芳賀孝成: 各種スランプロス低减型 流動化剂を用いた高強度コンクリート，コンクリートエ 学年次論文報告集, Vol.9, No.1, pp.229-234, 1987.

12 ）地濃茂雄, 仕入豊和, 依田彰彦, 横室隆, 飛内圭之, 永 野徹：高強度マスコンクリートの強度発現性状に及ぽす 初期温度履歴条件の影響 その 2 水和進行性からの検 討, 日本建築学会大会学術講演梗概集 A（九州）, pp.523-524, 1989.

13 ）土木学会 コンクリート委員会 コンクリート標準示方 書改訂小委員会編：コンクリート標準示方書施工編, pp.56-57, 1996.

14 ）青木茂, 芳賀孝成: 連壁基礎における高強度コンクリー ト, 基礎工, Vol.19, No.8, pp.86-92,1991.

(1999.6.7受付)

\title{
STUDY ON APPLICATION OF HIGH STRENGTH AND SELF-COMPACTING CONCRETE FOR THE UNDERGROUND DIAPHRAGM WALL
}

\author{
Jun SAKAMOTO, Takeshi OHTOMO, Takefumi SHINDOH and Yasunori MATSUOKA
}

This study was performed to investigate the mix proportion of high strength and self-compacting concrete, which mixproportion strength was more than $80 \mathrm{~N} / \mathrm{mm}^{2}$, and application of the concrete for the underground diaphragm wall. It was confirmed that the concrete, which was consisted of low-heat portland cement, air entraining high-range water reducing agent, would be expected to have long-term development of strength because of very low rise of temperature and could be easily filled into the structure by tremie method. And it was also confirmed that the strength of the concrete after filling into the diaphragm wall was the same as the strength of the specimens, which were sampled before filling and cured by standard curing condition. 